R. V. Harris, in an introductory paper on hop problems, outlined, inter alia, the part that could be played in disease control by the breeding of resistant or tolerant varieties. 'There are always variations within such varioties, but $\mathrm{P}$. W. Talboys concluded that "variation in response to local environmontal factors will always tend to be large in varieties of intermediate resistance, but small in very sensitive or very resistant varieties". He also showed that resistance to Verticillium wilt depends on the more rapid completion of endodermal suberization, and the production of highly tolerant varieties is thus placed on a sure basis. East Malling has produced new varieties of black currant and a whole range of raspberries; R. L. Knight and Elizabeth Keep discussed patterns for remodelling varieties for resistance to aphids and Botrytis fungi, black currant varieties for new strig type and resistance to gall mite, gooseberry for spinelessness and resistance to American gooseberry mildew, and all for high yield and quality. There are also somo interesting interspecific crosses.

One might perhaps predict for the future that, as the groat practical work of the Station is now to reduce costs for the industry, more assessment will become necessary of the relative expenditure required for the various new operations introduced by research. There is nothing mercenary about this, for as the World wants more food, it wants it without the expenditure of undue human energy, and the scientific measure of such energy is ultimately based on its cash value. In reviewing the sustained work of the Station as a whole I have, unfortunately, omitted mention of twenty-five detailed papers, a general review and four bulletins for fruit growers which indeed occupy the bulk of the report. Apologies to the authors of these, but warmest congratulations on the Jubilee, thus fortified by an acute appreciation of the Station's work.

J. GRAINGER

\title{
SCIENCE IN THE JUNIOR SCHOOL
}

$I^{\mathrm{N}}$ $\mathrm{N}$ the initial competition for the Guinness Awards for Science Teachers in Training, held in 1963, the first prize was gained for their joint work by two students, Sheila Stafford and David Horswill, of the City of Leeds Training College. A slightly edited version of their entry has now been published as a special Supplement to The Science Teacher (7, No. 7; July 1964). It needs to be appreciated that, at the time when they wore producing their essay, the classroom experience of these two students was limited mainly to their periods of school practice and observation of teachers in action, so that they were drawing on their own academic studies, which included among othors the writings of Susan Isaacs, J. Piaget, and Cyril Burt.

Following a trend which is gathering strongth, they have broken away from the tradition that for young children nature study provides tho best introduction to science. Instead, they consider that the aim should be to holp boys and girls to gain confidence in scientific methods of enquiry and experiment, and train them to think methodically and logically, so that, within the scope of their abilities, they may gain an understanding of selected aspects of the world around them, in accordance with the needs of society. There should be no fixed syllabus, although, while allowing for flexibility, the course should not lack cohesion; and the driving-power should come from the children's own interests, the toachor sensing "when to follow, when to discuss, explain, teach or guide". In this way they believe the teacher can provide oppcrtunities for progressive observation and experiment which will lead to deeper understanding and the formulation of simple, genoral laws -as, for example, those relating to elementary magnetism and the reflexion of light.

'The essay includes sections on such topics as the help teachers can give in building up concepts, project work, and the value of class discussion; and it ends with an outline syllabus for children of soven to eleven years old. Although somewhat discursive and repetitive, it is a commendable piece of work, well in line with modern developments in the junior school; and it indicates that the scheme of Guinness Awards for Science Teachers in Training is serving a useful cause. It also highlights the need for more attention to be directed, at full research level, to a still greater cause, that of gaining a better understanding of individual attitudes, interests and abilities, in relation to science, throughout the whole of tho educational period.
R. Whatherall

\section{INDUSTRIAL DESIGN}

$\mathrm{I}^{\mathrm{N}}$ a debate in the House of Lords on June 17 Lord Peddie directed attention to the annual roport of the Council of Industrial Design and referred to the recent Fiolden Report on Engineering Design. The latter had expressed tho view that Britain's share of international trade in engineering goods had been declining because, in spite of many notablo successes, many British products woro boing outclassed in performance, reliability and sales appeal. Lord Peddie reforred to the importance of raising the standards of design. He thought that design in industry was never more important than it is to-day, and he also thought it unfortunate that industrial design was mentally closely identified with art. During the past twenty years the Council of Industrial Design had played a significant part in increasing the awareness that good design was an expression of creative gonius and of the importance of the whole subject. But he thought that it was necessary to increase substantially the work of the Council and to extend its activities into designs not at present covered by the Design Contro, capital goods and engineering industries. $H_{\Theta}$ thought a closer associ- ation would be justified between the Council and the Department of Scientific and Industrial Research. It was oncouraging to soe that the Royal College of Arts was now recognizing the importance of greater attention to the problem of industrial design, and Lord Peddie also referred to tho proposal for a university on design and tochnology in northern Middlesex.

The Minister of State (Board of Trade), Lord Drumalbyn, referred briefly to the development of industrial design to put the question of design into perspective. Ife pointed out that the new profession of industrial designing had formally been recognized loss than thirty years ago (1936) when the Royal Society of Arts founded the distinction of Royal Designer for Industry, of which there were now 48 in addition to 13 honorary foreign holders of the distinction. The Council of Industrial Design and its Scottish Committeo had been formod in 1944 to promoto by all practical means the improvement of design in the products of British industry, and in 1956 the Design Centre had been established at 28 Haymarket, London, S.W.I: the 